\title{
Modernisasi Pendidikan Pesantren Perspektif Azyumardi Azra
}

\author{
Muhammad Heriyudanta \\ IAIN Ponorogo \\ yudanta10@gmail.com \\ DOI: $10.18326 /$ mudarrisa.v8i1.145-172
}

\begin{abstract}
Abstrak
Tulisan ini bermaksud untuk meneliti dan memetakan pemikiran Azyumardi Azra tentang pendidikan Islam, namun memfokuskan kajian pada lembaga pendidikan Islam informal, pesantren. Dalam pandangan Azra, pesantren sebagai bagian yang tidak terpisahkan dengan pendidikan nasional telah diakui perannya sebagai agen perubahan sosial. Karenanya, ia dituntut untuk terus memainkan perannya secara proaktif dan dinamis. Kehadirannya diharapkan terus menjadi cahaya pencerah, membawa perubahan, sekaligus memberi kontribusi berarti bagi perbaikan kehidupan seluruh umat manusia pada umumnya dan umat Islam khususnya. Namun,seiring dengan perkembangan zaman, lebihlebih di era globalisasi seperti sekarang ini, pesantren kini menghadapi masalah-masalah (akibat dampak globalisasi) yang tidak kunjung selesai bahkan hingga membenang kusut. Akibatnya, pesantren kini dipandang oleh banyak kalangan (baik dari pengelola pendidikan Islam itu sendiri maupun masyarakat luas) sebagai pendidikan kelas dua (second class). Karena itu, agar pesantren mampu terus memainkan perannya dengan baik, yakni menjadi produsen yang menghasilkan manusia-manusia yang berilmu, berteknologi, berketerampilan tinggi, dan sekaligus beriman dan beramal saleh, ia harus dimodernisasi secara serius sesuai dengan kerangka modernitas. Sebab, mempertahankan pemikiran kelembagaan Islam "tradisional" hanya akan memperpanjang nestapa ketidakberdayaan kaum muslim dalam berhadapan dengan kemajuan dunia modern.
\end{abstract}


This paper intends to examine the Azyumardi Azra thinking about Islamic education and focuses on informal Islamic education institutions, boarding school (Pesantren). In view of Azra, boarding schools as an integral part of national education has been recognized its role as agents of social change. Therefore, they are required to continue their role in a proactive and dynamic way. Theirpresence is expected to bring about change, as well as provide significant contributions to improve the people lives in general and Muslims in particular. However, along with the times, especially in globalization era, boarding schools are facing problems due to the impact of globalization, which is not finished even to the fibrous tangles. As a result, boarding schools are now regarded by many people(both of the Islamic education manager and the broader community) as a second class education. Therefore, in order to continue its role, i.e. to producehuman beings who have knowledge, technology, highly skilled, devout and do good behave, they must be seriously modernized in accordance with the framework of modernity. In case of maintaining the Islamic "traditional" institutional thinking will only prolong the agony of Muslim helplessness in dealing with the development of modern world.

Kata kunci: pesantren, modernisasi, Azyumardi Azra

\section{Pendahuluan}

Salah satu lembaga pendidikan di Indonesia yang mempunyai kekhasan tersendiri dan berbeda dengan lembaga pendidikan yang lainnya adalah pesantren. Institusi ini lahir, tumbuh, dan berkembang telah lama. Bahkan, semenjak belum dikenalnya lembaga pendidikan lainnya di Indonesia, pesantren telah hadir lebih awal. Itu sebabnya, pesantren pada umumnya dipandang sebagai lembaga pendidikan asli (indigenous) Indonesia (Azra, 2000:87). Hal ini senada dengan apa yang ditegaskan oleh Malik Fajar. Ia menegaskan bahwa, dalam sejarah pertumbuhan dan 
perkembangan pendidikan Islam di Indonesia tidak dipungkiri bahwa pesantren telah menjadi semacam local genius institution (Fajar, 1998:60).

Model pendidikan pesantren yang berkembang di seluruh Indonesia mempunyai nama dan corak yang sangat bervariasi, di Jawa termasuk Sunda dan Madura disebut pondok atau pesantren (Dhofier, 1990:18), sementara di Aceh di kenal dengan istilah dayah, rangkang, meunasah. dan di Sumatra Barat disebut dengan nama Surau (Rahardjo, 1985:5). Dan sekarang, lembaga pendidikan khas tersebut lazim diterima oleh umum sebagai pondok pesantren.

Adapun secara terminologi, ada beberapa pandangan yang mengarah kepada definisi pesantren. Menurut Muchtar Buchori pesantren adalah bagian dari struktur internal pendidikan Islam di Indonesia yang diselenggarakan secara tradisional dan memandang Islam sebagai cara hidup (Thoha, 1990:3). Sementara itu, Amin Abdullah mendeskripsikan, bahwa dalam berbagai variasinya, dunia pesantren merupakan pusat persemaian, pengamalan dan sekaligus penyebaran ilmu-ilmu keislaman (Abdullah, 1995:3).

Sedangkan dalam penamaan pesantren sendiri terdapat dua pandangan yang melatar belakanginya. Pandangan yang pertama terkait dengan terminologi yang ada di kalangan Hindu. Kata pesantren berakar dari kata santri dengan awalan "pe" dan akhiran "an". Menurut C.C. Berg istilah tersebut berasal kata India Shastri, berarti orang-orang yang tahu buku-buku suci Agama Hindu, atau seorang sarjana ahli kitab suci 
Agama Hindu. Kata Shastri sendiri berasal dari kata shastra yang berarti buku- buku suci, buku-buku Agama atau pengetahuan.

Pendapat kedua menyatakan bahwa pesantren memiliki hubungan historis dengan Timur Tengah. Terkait dengan pengaruh Timur Tengah ini sudah banyak yang membuktikan terutama mereka yang melakukan ibadah haji di Mekah dan Madinah. Mekah dan Madinah bagi ulama Indonesia tidak semata tempat untuk melakukan ibadah haji tetapi tempat untuk mencari ilmu, terutama dengan menghadiri pengajian di Masjidil Haram dan Masjid Nabawi. Adanya perbedaan pendapat ini tidak berarti pendapat satu yang benar, sementara pendapat lainnya salah. Kedua pendapat ini saling mengisi, dan memang pesantren tidak bisa dilepaskan dari unsur-unsur Hindu yang sudah lebih awal ada di Indonesia dan unsur-unsur Islam Timur Tengah di mana Islam berasal (Haningsih, 2008:30).

Dilihat dari aktivitas pendidikannya, pesantren memiliki beberapa ciri khas yang menjadi pembeda dengan lembaga pendidikan lain. Ciri khas tersebut misalnya menurut K.H. Yusuf Hasyim, pimpinan pesantren Tebuireng Jombang, adalah kekhasan pesantren yang secara fungsional sebagai institusi yang meliputi fungsi pendidikan, dakwah, kemasyarakatan, dan bahkan perjuangan di masa kolonial (Hasyim, 1988:88). Selanjutnya, Mukti Ali, yang juga alumni pondok pesantren Tremas Pacitan Jawa Timur, mengidentifikasi beberapa karakteristik pesantren sebagai berikut: a) adanya hubungan yang akrab antara santri dan kiai, hal ini karena mereka tinggal dalam pondok; b) tunduknya santri pada kiayi; c) hidup hemat dan sederhana benar-benar dilakukan di 
pesantren; d) semangat menolong diri sendiri amat terasa dan kentara di kalangan santri di pesantren; e) jiwa tolong-menolong dan suasana persaudaraan sangat mewarnai pergaulan di pondok pesantren; f) kehidupan berdisiplin sangat ditekankan dalam kehidupan pesantren; g) berani menderita untuk mencapai suatu tujuan adalah salah satu pendidikan yang diperoleh santri di pesantren; h) kehidupan agama yang baik dapat diperoleh santri di pesantren (Ali, 1987:17).

Selanjutnya, ditinjau dari segi historisnya, Pesantren merupakan bentuk lembaga pendidikan pribumi tertua di Indonesia. Pesantren sudah dikenal jauh sebelum Indonesia merdeka, bahkan sejak Islam masuk ke Indonesia, pesantren terus berkembang sesuai dengan perkembangan dunia pendidikan pada umumnya. Hal ini menandakan bahwa pesantren merupakan lembaga pendidikan yang mempunyai akar sejarah keindonesiaan.

Pendidikan di pesantren semula merupakan pendidikan agama yang dimulai sejak munculnya masyarakat Islam di Negara ini. Beberapa abad kemudian penyelenggaraan pendidikan ini semakin teratur dengan munculnya tempat-tempat pengajian atau disebut "nggon ngaji" yang telah merumuskan kurikulumnya, yakni bahasa Arab, tafsir, Hadits, taudid, fiqh, akhlak-tasawuf dan lain-lain. Bentuk ini kemudian berkembang dengan pendirian tempat-tempat menginap bagi para pelajar (santri), yang kemudian disebut pesantren (Azizy, 2002:42).

Pesantren sebagai komunitas dan sebagai lembaga pendidikan yang besar jumlahnya dan luas penyebarannya di berbagai pelosok tanah air telah banyak memberikan peran dalam membentuk manusia Indonesia 
yang religius. Lembaga tersebut telah, tengah, dan terus memberikan kontribusi yang luar biasa bagi berdirinya dan kontinuitas kemajuan bangsa Indonesia. Ia telah melahirkan banyak pemimpin bangsa Indonesia di masa lalu, kini dan agaknya juga di masa datang. Lulusan pesantren telah memberikan partisipasi aktif dalam pembangunan bangsa.

Jika kita menunjuk beberapa nama yang memiliki peran besar dalam sejarah perjuangan bangsa Indonesia, maka tentunya nama itu tidak asing lagi, seperti Hadratusy Syeikh Hasyim Asy'ari (pendiri pesantren Tebuireng dan NU) yang dedikasinya terhadap kemerdekaan bangsa tentu tidak diragukan. Hal ini tentu dibuktikan bahwa Beliau merupakan penerima gelar Pahlawan Kemerdekaan. NU yang hingga sekarang menjadi pilar "nasionalisme Indonesia" adalah karya besar kyai tradisional yang memiliki visi bagi pengembangan Indonesia modern sekarang ini.

Putranya, KH. Wahid Hasyim adalah tokoh penerus kyai tradisional yang sumbangannya bagi kemerdekaan tidak diragukan lagi. Bersama tokoh-tokoh bangsa ini, beliau yang sangat konsistem mengembangkan multikulturalitas dan pluralitas bangsa. Ketika ada pemikiran menjadikan "Piagam Jakarta" sebagai pilar kebangsaan maka beliaulah yang menyatakan bahwa membangun kebersamaan jauh lebih penting dibanding mempertahankan kalimat "Ketuhanan Yang Maha Esa dengan Kewajiban menjalankan syariat Islam bagi pemeluknya”. Tujuh kata yang akan menjadikan Indonesia tidak bersatu padu lalu dihilangkan. Hal ini menggambarkan bahwa pandangan tentang 
multikulturalitas dan pluralitas itu telah menjadi sikap hidup bagi kyai tradisional tersebut.

Di era kemungkinan terpecah-pecahnya negara bangsa akibat ideologi yang saling bertentangan, yaitu Islamisme, Nasionalisme dan Komunisme, maka kyai-kyai NU kemudian mengambil jalan tengah mendukung konsep Nasakom yang digagas oleh Soekarno yang saat itu sangat powerfull. Kyai-kyai NU juga mendukung terhadap keputusan Presiden Soekarno untuk melakukan Dekrit Presiden 5 Juli 1959 sebagai cara untuk mengakhiri perdebatan di dalam Sidang Konstituante yang berlarut-larut selama 3,5 tahun. Perdebatan itu tidak menghasilkan keputusan tentang dasar negara apakah Islam, Komunisme atau Pancasila. Dekrit Presiden untuk kembali ke Pancasila, UUD 1945 dan NKRI merupakan keputusan yang harus diambil karena menghindarkan keterpecahbelahan kesatuan dan persatuan bangsa.

\section{Metode Penelitian}

Penelitian ini merupakan penelitian jenis kepustakaan (library research). Penelitian kepustakaan adalah penelitian yang dilakukan dengan cara mengumpulkan data, informasi, dan berbagai macam data-data lainnya yang terdapat dalam kepustakaan (Subagyo, 1991:109). Dengan mengutarakan jenis penelitian ini, fokus dan langkah-langkah yang akan dalam penelitian ini menjadi semakin jelas. Mengenai sumber data, karena tulisan ini sifatnya adalah kajian pustaka, maka obyek yang dapat dijadikan sumber dibagi menjadi dua, yaitu primer dan sekunder. Data primer adalah adalah buku, jurnal, buletin dan karya ilmiah yang ditulis 
oleh Azyumardi Azra (Saukan, 2000:29). Sedangkan data sekunder adalah buku buku masih dianggap relevan dengan kajian penelitian (Arikunto, 1993:131).

Pendekatan yang digunakan dalam penelitian ini adalah pendekatan filosofis. Pendekatan filosofis digunakan untuk merumuskan secara jelas hakekat yang mendasari konsep-konsep pemikiran (Bakker dan Zubair, 1990:92). Lebih lanjut pendekatan filosofis dalam penelitian ini digunakan untuk mengkaji secara mendalam beberapa problem krusial yang dihadapi pesantren. Sementara teknik pengumpulan datanya menggunakan teknik dokumentasi. Teknik dokumentasi adalah metode pengumpulan data yang dilakukan dengan cara mencari data tentang variabel penelitian dari berbagai macam dokumentasi, baik yang berupa catatan, transkip, buku, surat kabar, majalah, jurnal, dan lain sebagainya (Arikunto, 1980:62).Untuk mengarahkan keakuratan dan ketepatan terhadap data yang diteliti, metode analisa yang digunakan yaitu content analysis.

Metode content analysis merupakan sebuah analisis terhadap kandungan isi yang tidak akan lepas dari interpretasi sebuah karya. Secara metodologis, analisis ini mencoba menawarkan asumsi-asumsi epistemologis terhadap pemahaman yang tidak hanya berkutat pada analisa teks tetapi juga menekankan pada konteks yang melingkupinya serta kontekstualisasinya dalam masa yang berbeda (Stempel, 1983:3). Adapun langkah kongkritnya adalah menentukan hubungan antar katageri dengan yang lain, melakukan analisis dan interpretasi sesuai dengan peta penelitian yang dibimbing oleh masalah dan tujuan 
penelitian. Proses analisis data ini dilakukan untuk mewujudkan kontruksi teoritis sesuai dengan masalah penelitian.

\section{Pembahasan}

\section{Pesantren dalam Kesejarahan}

Pesantren memiliki kontribusi yang besar dalam keikutsertaannya mencerdaskan bangsa, dimana pendidikan pesantren di Indonesia telah berumur lebih dari ratusan tahun, bahkan sebelum Indonesia merdeka dari penjajahan negara asing. Hal tersebut dapat dilihat dari peran para ulama atau kiyai dalam keikutsertaannya dalam meraih kemerdekaan. sebagaimana Pangeran Diponeogoro, Imam Bonjol, K.H. Ahmad Dahlan dan K.H. Hasyim Asy'ari.

Di era Orde Baru, hubungan NU, Pesantren dan Pemerintah sempat saling mencurigai bahkan antagonistik. Puncaknya adalah ketika Pemerintah Orde Baru, Soeharto, menetapkan Pancasila sebagai satusatunya asas bagi seluruh organisasi di Indonesia. NU dengan kyai pesantrennya kemudian tampil lagi dalam kerangka untuk mencairkan hubungan antara Pemerintah dengan organisasi sosial keagamaan, yang kala itu masih enggan menerima Pancasila sebagai satu-satunya asas. Melalui musyawarah nasional (Munas) di Pesantren Salafiyah Syafiiyah Situbondo, maka dengan tegas NU menyatakan bahwa NU menerima Pancasila sebagai satu-satunya asas dan kemudian diikuti oleh organisasi sosial keagamaan lainnya.

Ketika orang ribut tentang tidak perlu lagi menjadikan Pancasila sebagai pemersatu bangsa, dasar negara dan NKRI, maka sekali lagi 
orang pesantren, Kyai Sahal Mahfudz, pimpinan Pesantren Maslakul Huda Pati Jawa Tengah, di dalam pidatonya menegaskan bahwa Pancasila, UUD 1945 dan NKRI adalah sesuatu yang final sebagai dasar negara, landasan yuridis dan bentuk negara Republik Indonesia. Kaum pesantren yang dilabel dengan tradisional ternyata adalah pembela republik ini di dalam situasi yang krusial. Makanya, pesantren memiliki peran signifikan dalam percaturan nasionalisme kebangsaan di negeri ini. Peran pesantren, NU dan para kyainya seperti ini tentunya didasari oleh semangat keagamaan yang rahmatan lil 'alamin, agama yang memberi keselamatan kepada semuanya.

Selain itu, dalam sejarah perjuangan umat Islam Indonesia, terutama pada masa perjuangan kemerdekaan, masyarakat pesantren, santri dan ulama merupakan salah satu ujung tombak pergerakan melawan penjajah. Dalam perang 10 Nopember 1945 di Surabaya, misalnya, kaum ulama mengeluarkan "Resolusi Jihad" yang disuarakan oleh K.H. Hasyim Asy'ari sehingga umat Islam bangkit melawan penjajah dengan perhitungan mati syahid. Di Aceh, kaum ulama yang sebagiannya juga tokoh tarekat mempelopori perang melawan penjajah pada masa dulu. Hikayat Perang Sabi merupakan syair yang digubah para ulama Aceh untuk mengobarkan semangat jihad dan mati syahid bagi rakyat Aceh dalam mengusir kaum kaphe (kafir) atau penjajah (http//nursyam.sunan-ampel.ac.id).

Tradisi pesantren yang oleh Dhofier (2009:125) disebut sebagai penerus tradisi peradaban melayu nusantara memiliki dasar pandangan keagamaan yang sudah dipadukan dengan modernitas. Meskipun 
pesantren pada awalnya bermula dari ide brillian para kiyai dan didirikan di pelosok desa, diharapkan pesantren mampu berkolaborasi dengan aspek komoderenan yang semakin berkembang. Dalam perjalanannya ditemukan pesantren yang secara senang hati melakukan perubahan secara bertahap, namun tidak sedikit pula pesantren yang berubah secara setengah- setengah bahkan tetap bertahan dengan model tradisi lama sebagai ciri khas pesantren. Pesantren ini dikenal dengan pesantren tradisional atau pesantren salafi.

Pesantren tradisional dalam perjalanannya tidak bisa mengelak dari pengaruh modernisasi, terutama perkembangan zaman yang diiringi oleh kemajuan ilmu pengetahuan dan teknologi. Pesantren ini dihadapkan pada tantangan-tantangan yang ditimbulkan oleh kehidupan modern. Dan kemampuan pesantren dalam menjawab tantangan tersebut dapat dijadikan parameter seberapa jauh dia dapat mengikuti arus modernisasi. Jika dia mampu menjawab tantangan itu, maka akan memperoleh kualifikasi sebagai lembaga yang modern. Dan sebaliknya, jika kurang mampu memberikan respon pada kehidupan modern, maka biasanya kualifikasi yang diberikan adalah hal-hal yang menunjukkan sifat ketinggalan zaman, seperti kolot dan konservatif (Madjid, 1997:88).

Menurut pandangan Azra (2012:118), Pesantren di Indonesia berbeda dengan Negara di Timur Tengah. Hal tersebut dapat dilihat dari sikap lembaga pendidikan tradisional pesantren yang menerima system dan tuntutan perkembangan zaman. sebagaimana pendidikan di lingkungan pesantren sendiri yang mengadopsi sistem pendidikan umum seperti SMA, SMK tanpa meninggalkan tradisinya seperti pengajian atau 
materi belajar bersumber pada kitab kuning yang merupakan ciri khas pesantren sejak awal berdirinya. Berbeda dengan apa yang terjadi di Turki Usmani, tegas Azra, sistem pendidikan di Negara tersebut pada mulanya tidak menjadikan madrasah sebagai lembaga pendidikan tradisional Islam sehingga tidak menjadi sasaran pembaharuan. Pada masa Turki Usmani, pembentukan sekolah baru disesuaikan sistem pendidikan Eropa yang dituju- kan untuk kepentingan reformasi militer dan birokrasi. Seperti Sultan Mahmud II melakukan pembaharuan pendidikan dengan menghadirkan sekolah Rusydiyah yang sepenuhnya mengadopsi sistem pendidikan Eropa. Sehingga madrasah tetap pada posisisnya sebgai lembaga pendidikan tradisional, sedangkan sekolah Rusydiyah sebagai lembaga pendidikan modern.

\section{Tantangan Pesantren}

Dalam menghadapi gempuran modernisasi ini pesantren di Indonesia telah menunjukkan sikapnya yang cukup menarik,yakni, "menolak sambil mengikuti”. Artinya, pada awalnya dunia pesantren terlihat "enggan" dan "rikuh" menerima modernisasi, tetapi secara gradual, pesantren melakukan akomodasi dan konsensi tertentu untuk menemukan pola yang dipandangnya cukup tepat . Tetapi, semua akomodasi dan penyesuaian itu dilakukan pesantren tanpa mengorbankan esensi dan hal dasariah lainnya dalam eksistensi pesantren.

Sikap yang ditampilkan pesantren tersebut jika dikaji lebih jauh rasanya cukup bijak, cerdas, dan elegan. Bijak dan cerdas, sebab ketika profil kehidupan tidak relevan lagi dengan perkembangan yang ada, 
modernisasi sesungguhnya menjadi tuntutan dari segala aspek kehidupan, maka dibutuhkan sebuah perubahan dan pembaharuan dalam beberapa sektor yang perlu dibenahi. Elegan, karena upaya melakukan aksi modernisasi tersebut dengan tanpa mengorbankan esensi dan hal dasariah lainnya dalam eksistensi pesantren itu sendiri.

Namun demikian, Realitanya tidak semua pesantren di Indonesia bersedia menerima pembaruan tersebut. Terdapat banyak pesantren yang dipimpin oleh kiyai konservatif yang cenderung sangat resistan terhadap pembaruan pendidikan pesantren (Azra, 2000:125). Mereka masih kaku (rigid) mempertahankan pola salafiyah yang dianggapnya sophisticated dalam menghadapi persoalan eksternal. Memang, di sebagian dunia pesantren masih terdapat pola baku sebagai hal esensial dunia pesantren yang dinilai relatif ajek dan kontinu terkait sistem nilainya yang tercermin dalam tradisi keilmuan dan moralitasnya, yang secara epistemik-etik diakui turut menentukan cara pandang pesantren dalam menafsirkan realita yang dihadapi dan dalam memberikan respon terhadapnya. Ke-ajek-an dan kontinuitas yang ada pada pesantren tersebut, dalam beberapa sisi diidentifikasi sebagai penyebab terjadinya kesenjangan antara pesantren dengan derap modernisasi yang tengah berlangsung di dunia "luar" (Arif, 2008:169). Inilah sesungguhnya akar masalah yang menyebabkan pesantren menjadi lembaga pendidikan yang terbelakang.

Kendati banyak pesantren yang sudah memodernisasi pendidikannya dengan berbagai strategi yang dianggapnya mujarab, sebagaimana Dalam pandangan Masykur (2010:158), iklim politik 
nasional di era 1990-an menjadi salah satu bukti kemajuan para intelektual pesantren untuk lebih banyak berperan di bidang pengembagan ekonomi dan politik. Demikian pula munculnya santri menengah menjadi indikator penting untuk mengukur peran sosial-politik santri. Kemunculan organisasi berbasis Islam seperti Ikatan Cendekiawan Indonesia (ICMI) dan terbentuknya bank-bank syari'ah menjadi tolak ukur kiprah kalangan santri. hal ini menunjukkan bahwa pesantren telah mengambil bagian dalam penyelengaraan pendidikan khususnya di pedesaan bahkan dalam perkembangannya beberapa daerah telah berdiri pesantren bukan lagi di pedesaan, tetapi di daerah kota.

Namun harus diakui hingga saat ini, secara umum, dalam bidang pendidikan, pesantren dapat dikatakan kalah bersaing dalam menawarkan suatu model pendidikan kompetitif yang mampu melahirkan output (santri) yang memiliki kompetensi dalam penguasaan ilmu sekaligus skill sehingga mampunyai bekal yang cukup memadai untuk terjun kedalam kehidupan sosial yang terus mengalami percepatan perubahan akibat modernisasi yang ditopang kecanggihan sains dan teknologi. Kegagalan pendidikan pesantren dalam melahirkan sumber daya santri yang memiliki kecakapan dalam bidang ilmu-ilmu keislaman dan penguasaan teknologi tersebut secara sinergis berimplikasi terhadap kemacetan potensi pesantren sebagai salah satu agents of social change dalam berpartisipasi mendukung proses transformasi sosial bangsa.

Melihat relitas di atas, sebagai sebuah lembaga yang bergerak dalam bidang pendidikan dan sosial keagamaan, pengembangan pesantren harus terus didorong. Hal ini karena sudah tidak diragukan lagi 
bahwa pesantren memiliki kontribusi nyata dalam pembangunan pendidikan. Apalagi dilihat secara historis, pesantren memiliki pengalaman yang luar biasa dalam membina dan mengembangkan masyarakat. Jika pembaruan dan pengembangan pendidikan pesantren tidak didorong sehingga ia tidak bisa memberi responsi yang tepat terhadap tantangan zaman (bagi pesantren yang masih getol mempertahankan secara murni corak pendidikannya) dan tidak mampu menyelenggarakan pendidikan yang tampil di depan atau setidaknya setara, maka bisa dipastikan pesantren akan kehilangan relevansinya dan akar-akarnya dalam masyarakat akan tercerabut dengan sendirinya, walaupun ia merupakan lembaga pendidikan indigenous.

Menanggapi fenomena pesantren di atas Azra memberikan sumbangan pemikiran yang cerdas. Menurutnya, langkah sebagian pesantren yang memberikan responsi terhadap modernisasi tersebut dengan cara "menolak sambil mengikuti" sudah cukup baik, bahkan memukau. Namun, yang perlu dikritik adalah pesantren yang tetap getol mempertahankan corak pendidikannya, kendati hal tersebut sudah kehilangan relevansinya dengan realitas sosial yang mengitari. Pesantren dengan model tersebut baginya harus segera dimodernisasi sesuai dengan kerangka modernitas. Menurut Azra, pesantren hari ini harus mampu mencetak sumber daya manusia (SDM) yang unggul yang ditandai dengan SDM yang tidak hanya berkualitas pada aspek kognitif, tetapi juga pada aspek afektif dan psikomotorik. Dalam kerangka ini, SDM yang dihasilkan pondok pesantren diharapkan tidak hanya mempunyai perspektif keilmuan yang lebih integrative dan komprehensif antara 
bidang ilmu-ilmu agama dan ilmu-ilmu keduniaan tetapi juga memiliki kemampuan teoritis dan praktis tertentu yang diperlukan dalam masa industri dan pasca industri (Azra, 1999:48).

Berkaitan dengan hal tersebut, Mulyasa mengatakan bahwa peserta didik (santri) harus dibekali dengan berbagai kemampuan sesuai dengan tuntutan zaman dan reformasi yang sedang bergulir, guna menjawab tantangan globalisasi, berkontribusi pada pembangunan masyarakat dan kesejahteraan sosial, lentur, dan adaptif terhadap berbagai perubahan (Mulyasa, 2003:vi).

Untuk dapat memainkan peran edukatifnya dalam penyediaan sumber daya manusia yang berkualitas, jelas mensyaratkan pesantren untuk meningkatkan mutu sekaligus memperbarui model pendidikannya. Sebab, model pendidikan pesantren yang mendasarkan diri pada sistem konvensional atau klasik tidak akan cukup membantu dalam penyediaan sumber daya manusia yang memiliki kompetensi integratif baik dalam penguasaan pengetahuan agama, pengetahuan umum dan kecakapan teknologis. Padahal ketiga elemen ini merupakan prasyarat yang tidak bisa diabaikan untuk konteks perubahan sosial akibat modernisasi.

Di sebagian pesantren yang masih mempertahankan sistem konservatifnya tersebut umumnya memiliki masalah sebagai berikut; Pertama, dari segi kepemimpinan pesantren secara kukuh masih terpola dengan kepemimpinan yang sentralistik dan hierarkis yang berpusat pada satu orang Kiai. Ihwal pendirian pesantren memang mempunyai sejarah yang unik. Berdirinya pesantren biasanya atas usaha pribadi kiai. Maka dalam perkembangan selanjutnya dia menjadi figur pesantren. Pola 
semacam ini tak pelak mengimplikasikan sistem manajemen yang otoritarianistik. Pembaruan menjadi hal yang sangat sulit dilakukan karena sangat bergantung pada sikap sang kiai. Pola seperti ini pun akan berdampak kurang prospektif bagi kesinambungan pesantren di masa depan. Banyak pesantren yang sebelumnya populer, tiba-tiba "hilang" begitu saja karena sang kiai meninggal dunia.

Kedua, kelemahan di bidang metodologi. Telah umum diketahui bahwa pesantren mempunyai tradisi yang kuat di bidang transmisi keilmuan klasik. Namun karena kurang adanya improvisasi metodologi, proses transmisi itu hanya melahirkan penumpukan keilmuan. Dikatakan oleh Martin van Bruinessen, ilmu yang bersangkutan dianggap sesuatu yang sudah bulat dan tidak dapat ditambah. Jadi, proses transmisi itu merupakan penerimaan secara taken for granted. Muhammad Tholhah Hasan, mantan Menteri Agama dan salah seorang intelektual Muslim dari kalangan pesantren NU, pernah mengkritik bahwa tradisi pengajaran yang mendapatkan penekanan di pesantren itu adalah fiqih (fiqh oriented), sehingga penerapan fiqih menjadi teralienasi dengan realitas sosial dan keilmuan serta teknologi kontemporer.

Ketiga, masalah kurikulum pesantren yang sudah usang. Pada umunya pesantren sebagai lembaga pendidikan Islam, materi pembelajarannya lebih mengutamakan pelajaran agama Islam yang bersumber dari kitab-kitab klasik, seperti tauhid, hadis, tafsir, fiqih dan sejenisnya. Kurikulum didasarkan pada tingkat kemudahan dan kompleksitas kitab-kitab yang dipelajari, mulai dari tingkat awal, menengah dan lanjut (Nahrawi, 2008:28). Kurikulum pesantren yang 
statusnya sebagai lembaga pendidikan non-formal hanya mempelajari kitab-kitab klasik yang meliputi: Tauhid, Tafsir, Hadits, Fiqh, Ushul Fiqh, Tasawwuf, Bahasa Arab (Nahwu, Sharaf, Balaghah dan Tajwid), Mantiq dan Akhlak. Pelaksanaan kurikulum pendidikan pesantren ini berdasarkan kemudahan dan kompleksitas ilmu atau masalah yang dibahas dalam kitab. Jadi, ada tingkat awal, menengah dan tingkat lanjutan. Gambaran naskah agama yang harus dibaca dan dipelajari oleh santri, menurut Zamakhsyari Dhofier mencakup kelompok "Nahwu dan Sharaf, Ushul Fiqh, Hadits, Tafsir, Tauhid, Tasawwuf, cabang-cabang yang lain seperti Tarikh dan Balaghah". Itulah gambaran sekilas isi kurikulum pesantren tentang "salafi", yang umumnya keilmuan Islam digali dari kitab-kitab klasik, dan pemberian keterampilan yang bersifat pragmatis dan sederhana. Bahkan, menurut Nurcholish Madjid, dalam konteks pendidikan di pesantren, istilah kurikulum tidak dikenal di dunia pesantren, terutama masa prakemerdekaan, walaupun sebenarnya materi pendidikan sudah ada dan keterampilan itu ada dan diajarkan di pesantren. Kebanyakan pesantren tidak merumuskan dasar dan tujuan pesantren secara eksplisit dalam bentuk kurikulum. Tujuan pendidikan pesantren ditentukan oleh kebijakan Kiai, sesuai dengan perkembangan pesantren tersebut (Madjid, 2000:59).

Keempat, terjadinya disorientasi, yakni pesantren kehilangan kemampuan mendefinisikan dan memosisikan dirinya di tengah realitas sosial yang sekarang ini mengalami perubahan yang demikian cepat. Dalam konteks perubahan ini, pesantren menghadapi dilema antara 
keharusan mempertahankan jati dirinya dan kebutuhan menyerap budaya baru yang datang dari luar pesantren.

\section{Gagasan Baru Pesantren}

Dalam pemikiran Azra, problematika pesantren di atas dapat diatasi dengan pemecahan masalah sebagai berikut. Masalah pertama adalah masalah pesantren yang dari segi kepemimpinan pesantren secara kukuh masih terpola dengan kepemimpinan yang sentralistik dan hierarkis yang berpusat pada satu orang Kiai sehingga berimplikasi pada sistem manajemen yang otoritarianistik dan pembaruan sulit dilakukan karena bergantung pada figure seorang kiyai, dapat diselesaikan dengan pembaruan sistem manajemen dan kepemimpinan (Azra, 2000:127). Kepemimpinan yang semula besifat sentralistik dan hierarkis yang berpusat pada satu orang Kyai, harus ditransformasikan menjadi manajemen dan kepemimpinan kolektif. Dengan perubahan pola kepemimpinan semacam ini, pesantren sangat berpotensi untuk tidak merosot bahkan lenyap sepeninggal figur tokoh sentral seorang Kiai.

Masalah kedua adalah kelemahan di bidang metodologi, bisa diselesaikan dengan kontekstualisasi dan improvisasi metode pembelajaran atau bahkan membangun sebuah paradigma baru metode pembelajaran (Azra, 2000:127). Menurut Azra (2000:127), di tengah perubahan era global dan globalisasi yang terus meningkat intensitasnya, paradigma baru pembelajaran dan pendidikan seyogianya merupakan sebuah paradigma emansipatoris (Azra, 2000:55). Maksudnya adalah, paradigma pembelajaran yang sejak dari tingkat pandangan dunia 
filosofis (philosophical worldview), sampai ke tingkat strategi, pendekatan, proses, dan "teknologi pembelajaran" menuju ke arah pembebasan peserta didik dalam segenap eksistensinya (Azra, 2000:55). Paradigma ini, berbeda dengan paradigma "lama" yang masih mendominasi pembelajaran, atau bahkan dunia pendidikan pada umunya, yang justru membuat peserta didik menjadi terbelenggu, dan tidak lagi bebas mewujudkan keseluruhan (wholeness) potensi kependidikan dirinya.

Dalam paradigma pembelajaran emansipatoris ini, guru bukan lagi satu-satunya pemegang monopoli dalam proses pembelajaran (Azra, 2000:55). Tentu saja, ia tetap merupakan salah satu narasumber penting pembelajaran peserta didik, berkat ilmu dan pengalaman yang ia miliki. Tetapi, pada saat yang sama, kini ia harus lebih siap mendengar; lebih siap memberikan kesempatan kepada peserta didik untuk menyatakan pikiran dan ekspresi mereka. Bahkan, lebih dari pada itu, guru sepatutnya senantiasa mendorong dan merangsang para peserta didik untuk "bicara" mengekspresikan apa yang hidup dalam diri mereka, dan kalau perlu mempersoalkan berbagai substansi pembelajaran yang mereka terima secara kritis.

Dengan metode pembelajaran semacam ini tidak ada peserta didik yang hanya seperti botol kosong yang harus diisi guru atau menjadi objek pendidikan. Peserta didik yang diposisikan menjadi objek pendidikan ini disebut Paulo Freire dengan istilah "banking concept of education". Lihat beberapa karya Paulo Freire, salah satunya yang berjudul Paedagogy of the Oppressed. Dengan metode seperti ini pula pendidikan 
di pesantren akan bisa melahirkan sumber daya manusia yang lebih unggul.

Masalah ketiga merupakan kurikulum pesantren yang sudah usang di telan zaman. permasalahanini dapat diatasi dengan cara tidak jauh berbeda dengan masalah kedua, yakni kontekstualisasi kurikulum dengan zaman yang tengah berlangsung (Azra, 2000:24). Seiring dengan tuntutan zaman dan laju perkembangan masyarakat, pesantren yang pada dasarnya didirikan untuk kepentingan moral, pada akhirnya harus berusaha memenuhi tuntutan masyarakat dan tuntutan zaman. Orientasi pendidikan pesantren perlu diperluas, sehingga menuntut dilakukannya pembaruan kurikulum yang berorientasi kepada kebutuhan zaman dan pembangunan bangsa (Khozin, 2006:101).

Yang mendesak saat ini, sesuai dengan gencarnya pengembangan sumber daya manusia (SDM) adalah mengembangkan spesialisasi pesantren dengan disiplin ilmu pengetahuan lain yang bersifat praktis yang melalui jalur aplikasi teknologi sehingga kurikulumnya tidak terlalu bersifat akademik. Tidak mengurangi sifat ilmiah bila dikutip sinyalemen Az-Zarnuji yang mengatakan bahwa sebaik-baik ilmu adalah ilmu keterampilan (Az-Zarnuji, t.t.:4). Dengan demikian, pesantren sebagai basis kekuatan Islam diharapkan memiliki relevansi dengan tuntutan dunia modern, baik untuk masa kini maupun masa mendatang.

Azyumardi menawarkan gagasan agar lembaga pendidikan tradisional Islam bernama pesantren itu memasukkan ilmu-ilmu umum seperti aljabar, berhitung, kesenian, olahraga, bahasa internasional dan sebagainya, bahkan juga keterampilan yang dibutuhkan dan selaras 
dengan zaman (Masruroh dan Umiarso, 2004:174). Itu semua dilakukan dengan harapan agar pesantren tidak hanya menjalankan peran krusialnya dalam tiga hal pokok, yakni untuk transmisi ilmu-ilmu dan pengetahuan Islam (transmission of Islamic Knowledge), pemeliharaan tradisi Islam (maintenance if Islamic tradition), dan reproduksi ulama (reproduction of 'ulama') (Azra, 2002:89).Tetapi pesantren juga diharapkan bisa mencetak sumber daya manusia yang menguasai ilmu agama sekaligus umum. Dengan demikian, mereka dapat melakukan mobilitas pendidikan. Tidak hanya itu, pesantren juga didambakan mampu mencetak santri yang memiliki keterampilan, keahlian atau lifeskills (khususnya dalam bidang sains dan teknologi yang menjadi karakter dan cirri masa globalisasi) yang membuat mereka memiliki dasar competitive advantage dalam lapangan kerja, seperti dituntut di alam globalisasi (Azra, 2000:136).

Tambah Azra, pengembangan competitive advantage atau competitive edge di dunia pesantren merupakan bukan hal mudah. Sebab, pengembangan itu bukan hanya memerlukan penyediaan SDM guru yang qualified, laboratorium/ bengkel kerja dan hardwere lain, tetapi juga perubahan sikap teologis dan budaya. Bukan rahasia lagi, paham teologis yang dominan di kalangan pesantren masih cenderung meminggirkan ilmu yang berkenaan dengan sains dan teknologi, karena secara epistemologis dianggap tidak atau kurang syah, karena sains dan teknologi merupakan produk rasio dan pengujian empiris. Lebih jauh, budaya sains dan teknologi masih kurang mendapat tempat dalam masyarakat kita umumnya (Azra, 2000:136). 
Dan terahir, untuk masalah keempat adalah terjadinya disorientasi, yakni pesantren kehilangan kemampuan mendefinisikan dan memosisikan dirinya di tengah realitas sosial yang sekarang ini mengalami perubahan yang demikian cepat. Dalam konteks perubahan ini, pesantren menghadapi dilema antara keharusan mempertahankan jati dirinya dan kebutuhan menyerap budaya baru yang datang dari luar pesantren. menurut Azra pesantren bisa menyelesaikan masalahnya dengan mengimplementasikan kaidah hukum "Al-Mukhafadzatu 'ala alqadim al-ashalih wa al-akhzu bi al-jadid al-ashlah, artinya melestarikan nilai Islam yang baik dan mengambil nilai-nilai baru yang sesuai dengan konteks zaman agar tercapai akurasi metodologis dalam mencerahkan peradaban bangsa (Masruroh \&Umiarso, 2004:214).

Dengan mengaplikasikan kaidah tersebut secara baik, tentu pesantren kini sudah memiliki sikap yang jelas dalam mendefinisikan dan memosisikan dirinya di tengah realitas sosial yang kini mengalami perubahan yang sangat cepat. Jika tradisi besar Islam direproduksi dan diolah kembali, umat Islam akan memperoleh keuntungan yang besar, diantaranya adalah memiliki "tradisi baru" yang lebih baik. Maka ketika pesantren tampil dengan wajah baru tentu akan menciptakan apa yang disebut dengan modernisasi pendidikan pesantren dengan tradisi baru. Untuk itu, tidak arif rasanya jika para pengelola pendidikan pesantren menutup diri dari derap modernisasi yang sesungguhnya harus diakui menawarkan nilai-nilai baru yang baik (meskipun ada juga yang buruk). Apabila pesantren ingin progresif dan relevan dengan zaman, pesantren mesti merespon perkembangan zaman dengan cara-cara kreatif, inovatif, 
dan transformatif. Dalam kerangka ini, pesantren hanya dituntut untuk cerdas dan selektif dalam mendialogkan diri dengan modernisasi.

Dengan demikian pula era globalisasi yang selalu menuntut setiap orang mempunyai power dan skill dalam mengarungi dunia yang semakin kompetitif dan out put yang tetap survive dan exis terlahir dari pondok-pondok pesantren di Indonesia. Demikian juga lembaga pendidikan pesantren diharapkan mampu menjawab masyarakat dimana lulusan mampu memiliki kemampuan dalam keagamaan, dan setara dengan lulusan sekolah umum, sehingga para lulusan dapat melanjutkan ke jenjang pendidikan tinggi secara luas.

\section{Simpulan}

Pesantren telah menorehkan sumbangsih yang besar dalam proses mencerdaskan generasi bangsa. Namun, dalam konteks kekinian pesantren tidak bisa mengelak dari pengaruh modernisasi, terutama perkembangan zaman yang diiringi oleh kemajuan ilmu pengetahuan dan teknologi. Pesantren dihadapkan pada tantangan-tantangan yang ditimbulkan oleh kehidupan modern. Sedangkan kemampuan pesantren dalam menjawab tantangan tersebut dapat dijadikan parameter seberapa jauh dia dapat mengikuti arus modernisasi. Masalah yang dihapai pesantren terhadap arus modernisasi dapat diklasifikasikan sebagai berikut; Pertama, dari segi kepemimpinan pesantren secara kukuh masih terpola dengan kepemimpinan yang sentralistik dan hierarkis yang berpusat pada satu orang Kiai. Kedua, kelemahan di bidang metodologi, pesantren mempunyai tradisi yang kuat di bidang transmisi keilmuan 
klasik. Namun karena kurang adanya improvisasi metodologi, proses transmisi itu hanya melahirkan penumpukan keilmuan. Ketiga, masalah kurikulum pesantren yang sudah usang. Hal tersebut umunya pesantren sebagai lembaga pendidikan Islam, materi pembelajarannya lebih mengutamakan pelajaran agama Islam yang bersumber dari kitab-kitab klasik, seperti tauhid, hadis, tafsir, fiqih dan sejenisnya. Kurikulum didasarkan pada tingkat kemudahan dan kompleksitas kitab-kitab yang dipelajari, mulai dari tingkat awal, menengah dan lanjut. Keempat, terjadinya disorientasi, yakni pesantren kehilangan kemampuan mendefinisikan dan memosisikan dirinya di tengah realitas sosial yang sekarang ini mengalami perubahan yang demikian cepat.

Dari keempat persoalan tersebut Azra menawarkan solusi. Untuk permasalahan pertama dapat diselesaikan dengan pembaruan sistem manajemen dan kepemimpinan. Kepemimpinan yang semula besifat sentralistik dan hierarkis yang berpusat pada satu orang Kiai, harus ditransformasikan menjadi manajemen dan kepemimpinan kolektif. Dengan perubahan pola kepemimpinan semacam ini, pesantren sangat berpotensi untuk tidak merosot bahkan lenyap sepeninggal figur tokoh sentral seorang Kiai. Masalah kedua dapat diatasi dengan kontekstualisasi dan improvisasi metode pembelajaran atau bahkan membangun sebuah paradigma baru yang berorientasi pada paradigma emansipatoris. Masalah ketiga dapat diatasi dengan cara tidak jauh berbeda dengan masalah kedua, yakni kontekstualisasi kurikulum dengan zaman yang tengah berlangsung. Adapun masalah keempat dapat diatasi dengan mengimplementasikan kaidah hukum "Al-Mukhafadzatu 'ala al- 
qadim al-ashalih wa al-akhzu bi al-jadid al-ashlah, artinya melestarikan nilai Islam yang baik dan mengambil nilai-nilai baru yang sesuai dengan konteks zaman agar tercapai akurasi metodologis dalam mencerahkan peradaban bangsa.

\section{Daftar Pustaka}

Abdullah, A. (1995). Falsafah Kalam di Era Postmodernisme Yogyakarta: Pustaka Pelajar.

Ali, M. (1987). Beberapa Persoalan Agama Dewasa Ini. Jakarta: Rajawali Press.

Arikunto, S. (1980). Prosedur Penelitian: Suatu Pendekatan Praktek. Jakarta: Bina Usaha.

Arif, M. (2008). Pendidikan Islam Tranformatif. Yogyakarta: LKIS.

Azizy, A. Q. A. (2002). "Memberdayakan Pesantren dan Madrasah", dalam Ismail S.M. dkk. (ed.), Dinamika Pesantren dan Madrasah. Yogyakarta: Pustaka Pelajar.

Az-Zarnuji. (t.t.). Ta'lìm al-Muta'allim fì Thuruq al-Ta'limm. Semarang: Toha Putra.

Azra, A. (1999). Pendidikan Islam: Tradisi dan Modernisasi Menuju Millenium Baru. Jakarta: Logos Wacana Ilmu.

Azra, A. (2001). Esei-esei Intelektual Muslim \& Pendidikan Islam. Jakarta: Logos Wacana Ilmu.

Azra, A. (2000). Pendidikan Islam: Tradisi dan Modernisasi di Tengah Tantangan Milenium III. Jakarta: Logos Wacana Ilmu.

Azra, A. (2001). Esei-Esei Intelektual Muslim \& Pendidikan Islam. Jakarta: Logos Wacana Ilmu.

Bakker, A. dan Zubair, A. C. (1990). Metodologi Penelitian Filsafat. Yogyakarta: Kanisius.

Dhofier, Z. (1990). Tradisi Pesantren: Studi tentang Pandangan Hidup Kiai. Jakarta: LP3ES.

Fajar, M. (1998). Visi Pembaruan Pendidikan Islam. Jakarta: Lembaga Pengembangan Pendidikan dan Penyusunan Naskah Indonesia. 
Haningsih, S. (2008). "Peran Strategis Pesantren, Madrasah, dan Sekolah Islam di Indonesia", Jurnal Pendidikan Islam El-Tarbawi, No. 1. Vol. 1. hlm. 56.

Hasyim, M. Y. (1988). "Peranan dan Potensi Pesantren dalam Pembangunan", dalam Wolfgang Karcher dkk. (peny.), Dinamika Pesantren. Jakarta: P3M.

Khozin. (2006). Jejak-Jejak Pendidikan Islam di Indonesia: Rekonstruksi Sejarah untuk Aksi. Malang: UMM Press.

Madjid, N. (1997). Bilik-bilik Pesantren: Sebuah Potret Perjalanan. Jakarta: Paramadina.

Masruroh, N. \& Umiarso. (2004). Modernisasi Pendidikan Islam Ala Azyumardi Azra. Yogyakarta: LKIS.

Mulyasa, E. (2003). Kurikulum Berbasis Kompetensi, Konsep, Karakteristik dan Implementasi.Bandung: Remaja Rosdakarya.

Nahrawi, A. (2008). Pembaharuan Pendidikan Pesantren. Yogyakarta: Gama Media.

Rahardjo, M. D. (1985). Pesantren dan Pembaruan. Jakarta: LP3ES.

Subagyo, J. (1991). Metode Penelitian dan Praktek. Jakarta: Rhineka Cipta.

Saukah, A. (2000). Pedoman Penulisan Karya Ilmiah. Malang: IKIP Malang.

Stempel, G. H. (1983). Content Analysis, terj. Jalaludin Rahmat dan Arko Kasta. Bandung: Arai Komunikasi.

Syam, N. (t.t.). "Peran Signifikan Kebangsaan Kaum Pesantren", dalam http://nursyam.sunan-ampel.ac.id/?p=110. Akses tanggal 11 Oktober 2013.

Thoha, M. C. (1990). "Strategi Pendidikan Islam dalam Mengembangkan Manusia Indonesia yang Berkualitas", Makalah Seminar oleh KMA-PBS IAIN Walisongo, Semarang. 
Mudarrisa, Jurnal Kajian Pendidikan Islam, Vol. 8, No. 1, Juni 2016: 145-172 